Postprint of: Advances in the Economics of Religion 25, 2019, 120-131.

\title{
RELIGIOSITY AND ECONOMIC PERFORMANCE: THE ROLE OF PERSONAL LIBERTIES $^{1}$
}

\author{
LAURA MAYORAL AND JOAN ESTEBAN ${ }^{2}$
}

June 20, 2018

\begin{abstract}
JEL-Classification: Z12, J22

Key-words: Religiosity, Personal Liberties, Labor supply.

\section{INTRODUCTION}

What is the effect of religion on economic outcomes? Religion is a complex social phenomenon affecting individual choice and behavior through numerous channels. This contribution summarizes some of these effects. We focus on the causality direction from religiosity to economic performance, therefore skipping the potential influence that the economic environment and personal realizations can have on religious beliefs. ${ }^{3}$
\end{abstract}

The economics literature has emphasized several mechanisms that relate religion and economic outcomes in different directions. We shall focus on three dimensions: [i] religion has an [ambivalent] effect on human capital formation; [ii] religion fosters a set of attitudes that are beneficial for growth; and [iii] religious values may be detrimental for economic development as they might hinder innovation as well as reduce incentives for individual effort. We shall discuss these three issues in Section 2.

Sections 3 and 4 focus on an alternative mechanism, recently introduced by Esteban, Levy and Mayoral (2017a, ELMa hereinafter), through which religion can also be detrimental for economic outcomes, notably for individual labor supply. Religions typically impose on their affiliates a code of conduct that constrains their behaviour in a number of areas: this includes issues

\footnotetext{
${ }^{1}$ Laura Mayoral and Joan Esteban gratefully acknowledge financial support from the Spanish Ministry of Economy and Competitiveness Grant , through the Severo Ochoa Programme for Centres of Excellence in RD (SEV-2015-0563) and grant number ECO2015 - 66883-P, Generalitat de Catalunya project number 2017SGR1359, and the National Science Foundation grant SES-1629370.

${ }^{2}$ Mayoral: Institut d'Anàlisi Económica, CSIC, Barcelona GSE and University of Gothenburg; laura.mayoral@iae.csic.es. Esteban: Institut d'Anàlisi Económica, CSIC and Barcelona GSE; joan.esteban@iae.csic.es.

${ }^{3}$ This direction of causality has been the focus of numerous theories. Of particular relevance is the secularization hypothesis, that states that economic growth decreases religious beliefs and participation in religious services and reduces the influence of religious institutions on politics and governance. Marx (1843) viewed religion as resulting from poverty, the opiate of the have-nots. Solt, Habel, and Grant (2011) have obtained empirical evidence supporting Marx's view: inequality breeds religiosity.
} 
such as divorce, women's rights, abortion, gay sexuality, marriage, euthanasia, etc. Religious institutions have successfully managed to influence the state so that legal caps on those issues were established, implying that both religious and secular individuals have been effectively constrained by those laws. However, over the past fifty years many countries have significantly changed such regulations, giving rise to a rights revolution (Hitchcock et al, 2012). Section 3 quantifies the extent of the changes in regulation of personal liberties in Europe from 1960 to the present. These changes are likely to have affected in a different way religious and secular individuals: While the latter now face a more lax environment, the religious are still constrained by their own religion's code of conduct. Section 4 analyzes the impact of the expansion of the legal cap on liberties on individual effort, and argues that the former increases (contracts) labor supply among secular (religious) individuals. Section 5 examines the implications of these results on voting over redistribution and over the expansion of the cap on liberties ( Esteban, Levy and Mayoral 2017b, ELMb henceforth). Finally, Section 6 concludes by pointing at potentially fruitful new lines of research.

\section{RELIGIOSITY AND ECONOMIC OUTCOMES}

Several strands of research have stressed the positive effects of religion on economic development. A first channel highlights the contribution of religion to human capital formation. Access to schooling depends on the availability of educational infrastructure and, in many countries, that infrastructure is based on facilities originally developed by religious organizations to promote education and spread the faith. Becker and Woessmann (2009) argue that Protestant reformation promoted literacy because of its contention that everyone needed to read the Bible, and show that Protestants' higher literacy accounts for the whole gap in economic prosperity between Protestant and Catholic regions. A similar argument has been made with respect to Judaism (Botticini and Eckstein, 2012). Other authors have highlighted the role of missionaries in spreading mass education in Africa or America (Nunn 2010, 2014 and Carneiro 2015). The universal validity of this channel, however, has been contested. More recent evidence points towards the opposite direction: higher family religiosity is linked to poorer education performance and lower human capital. For instance, Darnell and Sherkat (1997) and Sherkat and Darnell (1999) document a strong negative effect of fundamentalism on educational achievement, net of other social background variables, and Berman (2000) uses a "club good" model to explain the very low labor supply by Ultra-Ortodox Jews.

A second mechanism linking religion and economic outcomes argues that religion fosters a set of attitudes that are beneficial for growth. This argument was pioneered by Weber (1904), whose central thesis is that Protestantism promotes attitudes such as work ethic and honesty that contributed to the success of the capitalism. ${ }^{4}$ Guiso, Sapienza and Zingales (2003) have shown that more religious people are more trusting (of other people and of public institutions and market

\footnotetext{
${ }^{4}$ This hypothesis has been examined in numerous papers (see Grier 1997, Ekelund et al. 2006, and Delacroix and Nielsen 2001) obtaining mixed results. More recently, Cantoni (2015) has used a "natural experiment" -the forced imposition of religious denominations as a consequence of the Peace of Augsburg (1555) - to investigate the differences in growth patterns across the Protestant and Catholic parts of the Holy Roman Empire, finding no positive effect of Protestantism on economic growth over the very long run (1300-1900).
} 
outcomes), as well as more trustworthy (less willing to break the law). Using cross-country regressions, Barro and McCleary (2003) and McCleary and Barro (2006) find that for a given level of church attendance, increases in religious beliefs (particularly belief in heaven, hell, and an after-life) have a positive impact on economic growth. ${ }^{5}$ From a theoretical perspective, Bénabou and Tirole (2006, 2011) and Levy and Razin (2012) have argued that beliefs in divine rewards and punishments can induce individuals to behave less opportunistically and more cooperatively.

A third mechanism points towards a set of values and beliefs associated to religion that, contrary to the previous channel, can be detrimental to economic progress. Christianity and science often have come into conflict with each other. Bénabou et al. (2015a) argue that a key pillar of long run economic growth is innovation and have shown that the more religious people are, in general, the less inclined to it. Bénabou et al. (2015b) also show that there is a negative correlation between religiosity and patents per capita using both international as well as U.S. data. Barro and McCleary (2003) and McCleary and Barro (2006) provide evidence showing a negative correlation between church attendance and economic growth and income. Campante and Yanagizawa-Drott (2015) exploit exogenous variation in religious practices -differences in the length of the Ramadan fasting period in the north and south hemisphere due to the rotating Islamic calendar- and find that Ramadan fasting has a robust negative effect on output growth in Muslim countries. They also report evidence showing that a higher exposure to religious practices has an impact on individual preferences that leads to a decrease in labor supply beyond the month of Ramadan itself, which in turn leads to a decrease in economic performance. The result that religiosity is associated with lower effort or labor supply has also been attested by abundant theoretical and empirical literature. ${ }^{6}$

ELMa have proposed an alternative channel through which religion can be detrimental for economic outcomes, notably for individual labor supply. As mentioned in the Introduction, religions impose on their members a number of constraints on their behavior: this includes what to eat, what to drink, how to dress, the use of free time, gender roles, the possibility of divorce, abortion, gay sexuality, marriage, etc. Many of these aspects have typically been regulated by laws that restrict their use for both religious and non-religious individuals. Over the past fifty years, however, many governments have significantly changed such laws: Women's rights for education or employment and the right over their bodies had expanded, along with gay rights and individuals' rights over ending their life. These changes in the regulations are likely to have affected in a

\footnotetext{
${ }^{5}$ The findings by Barro and McCleary are based on cross-country regressions and they are subject to numerous criticisms. See Durlauf et al. (2012) for a critique.

${ }^{6}$ The mechanism explored in the literature is typically based on the assumption that religious individuals value relatively more religious than economic activities. This takes different specifications. Iannaccone (1992) initiated a stream of papers in which this lower relative valuation of material benefits is introduced by assuming that the utility from consumption of material goods is subject to some sort of "psychological tax". This makes individuals to devote more time and effort to religious activities. A complementary explanation, also due to Iannaccone (1992, 1998), follows from the view of religious practice as a problem of demand for a "club good". In this case, members of a religious club experience an externality because their individual enjoyment depends on the intensity of commitment of the other members. Hence, it may be in the interest of the club members to impose highly restrictive rules of behavior in order to leave out the individuals with lower levels of religiosity. These restrictions would be geared towards making more attractive the allocation of time to religious activities, at the expense of productive activities. Besides Iannaccone, also Berman (2000), and Carvalho and Koyama (2016), among others, argue that religions strategically induce individuals to participate in costly rituals and hence reduce their material productivity.
} 


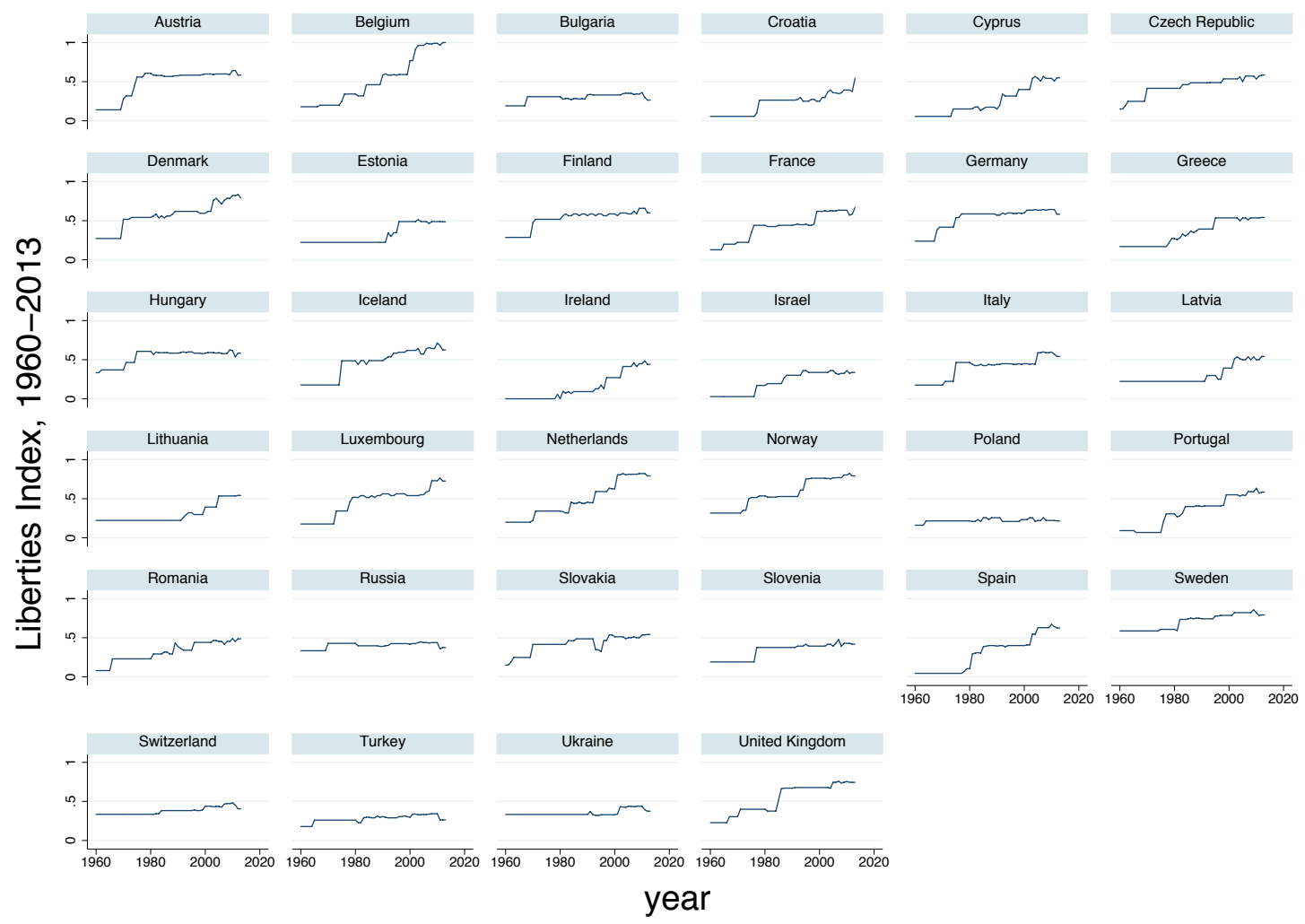

Figure 1. Legal evolution of the Personal Liberties index, 1960-2013

different way the restrictions faced by religious and secular individuals: While the latter now face a more lax environment, the religious are still constrained by their own religion's code of conduct. The following section examines the evolution of the regulation of personal liberties in Europe while Section 4 analyzes its impact on individual labor supply among secular and religious individuals.

\section{Constraints on Personal Liberties}

Most religions instill to their affiliates a number of constraints on the use of the above-mentioned personal liberties. Although religious individuals are free not to use those liberties (regardless whether the law forbids them or not), most if not all religions have successfully obtained the legal sanctioning of the religious norms by the state. Such legal caps on personal liberties have the effect of helping to implement the religious norms within the religious community. But they also have the effect of constraining the decisions of non-religious individuals. Thus, prohibiting by law the use of such liberties suggests that individuals have some utility externality by which 


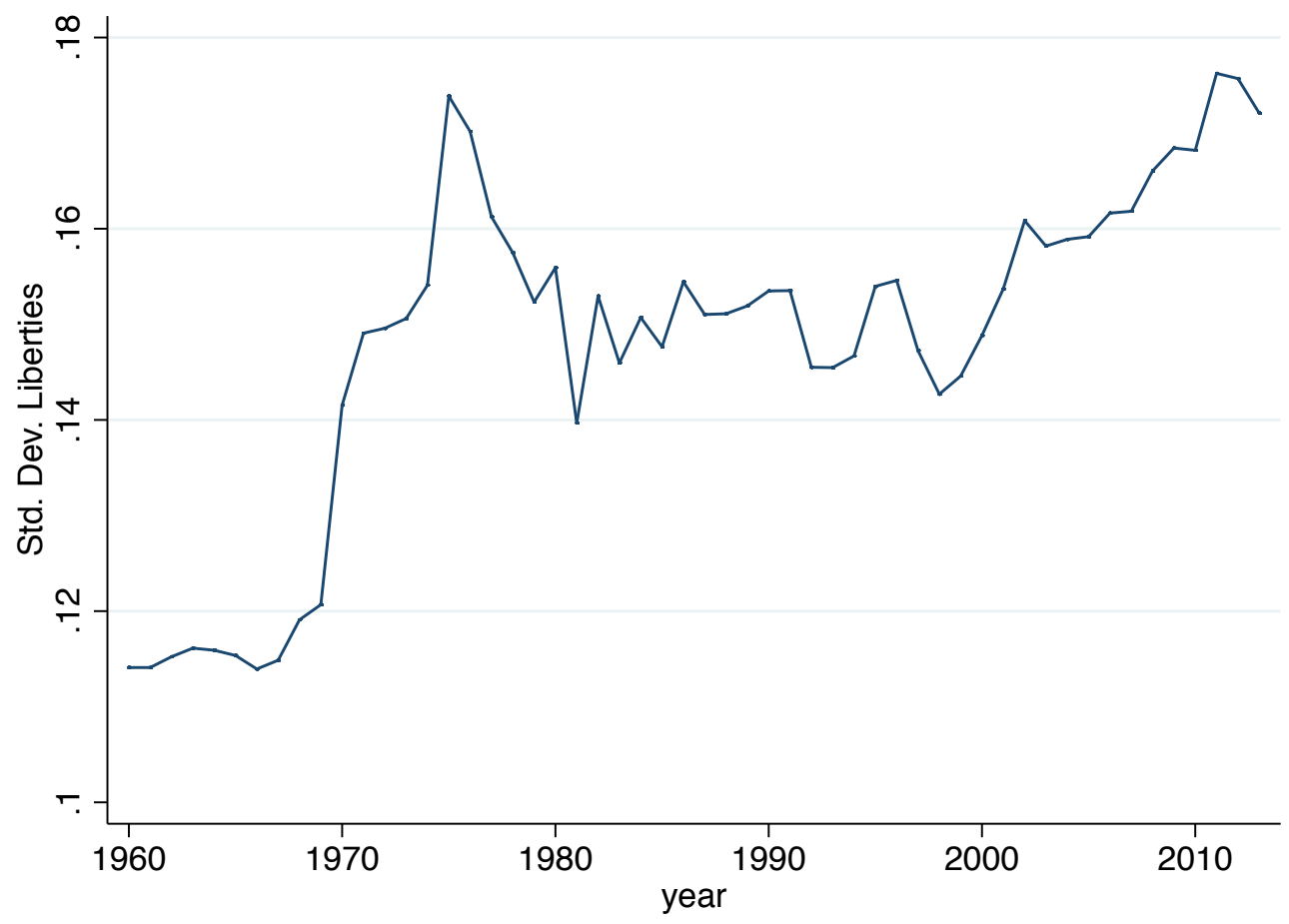

Figure 2. Cross-country std. deviation of the Personal Liberties index, 1960-2013

religious individuals feel offended (and seculars satisfied) from living in a world in which such liberties are permitted.

In order to quantify the change in the legal caps on personal liberties, ELMa construct an index of personal liberties based on the legal evolution of certain personal liberties from 1960 to 2013 that are or have been controversial in the recent past. The data reflect legislation on abortion, divorce, women's rights, LGBT rights and euthanasia for 34 European countries, and is assembled from various sources such as the UN, the EU parliament, World Bank, the Human Rights project, Pew Research Center, Freedom to Marry, etc. See ELMa for details on its construction. Figure 1 displays the evolution of the index of liberties for European countries from 1960 to the present, while Figure 2 depicts the cross-country standard deviation of the index for each year in the period 1960-2013. A higher value of the index indicates more liberal laws regulating personal liberties.

The main message from Figures 1 and 2 is that legal caps on personal liberties have greatly expanded in most European countries. The value of the index was relatively low and homogeneous across European states during the 60's. As shown in Figure 2, the 70's witnessed an important

\footnotetext{
${ }^{7}$ The partial lifting of the legal caps often finds an active opposition of religious and conservative groups. In many countries religious organisations advocate the tightening of laws regulating such personal liberties. In some cases violence is being used towards those that exercise such liberties, as for example in what is now defined as "anti-abortion terrorism". See the statistics for the US gathered by the National Abortion Federation (NAF).
} 
increase in the variability of the index, reflecting the legal changes occurring in some, but not all, of the countries in the dataset. During the 80's and 90's most of the countries in the sample kept introducing legal reforms so the variability of the index decreased as countries started to catch up. A new liberalisation wave in the 2000's has led the variability of the index to a new maximum. Differences across countries are substantial, as Figure 2 shows. The most conservative countries according to their Liberties index are Ireland (with an average value of the index of .15 across the period), Israel (.20) and Poland (.21). On the other side of the spectrum, the most liberal countries are Sweden at the top (.70 on average), followed by Norway and Denmark (.56). The following section analyzes how this unprecedented change in regulation has affected both religious and secular individuals.

\section{Religiosity, Personal Liberties ANd Labor SupPly}

While the legal caps on personal liberties have considerably loosened over the last decades, religious norms have remained fairly stable over the same period. The amplitude and the strictness of these norms varies through faiths, and also across religious communities. And of course the extent to which such norms effectively condition individual behavior also depends on the personal degree of religiosity. The literature has modelled the incidence of religion's rules following two main approaches. One is that norms directly shape individual preferences. The second approach is to model religious norms as a pure constraint on choices. For instance, religious individuals may enjoy some types of meat but accept the religious prohibition on its consumption.

ELMa follow the first approach: religion instills negative utility from violating the norms on these personal liberties. As in Becker (1996) they assume that religious norms are internalized as preferences. Individual preferences differ only in the valuation of the use of private liberties. As liberties broaden, secular individuals have a higher utility [all equal], and religious individuals a lower one. Then, under standard assumptions in consumer theory, the marginal utility of material consumption experienced by the secular should be higher than that by the religious [the rest all equal]. From this it follows that a lifting of the cap on liberties will be a positive (negative) incentive to work for the secular (religious) individuals. Hence, the wider the legal cap on liberties the more divergent will be the choices made by religious and secular.

The core of ELMa's model is as follows. Assume there are three goods which individuals can potentially enjoy. Two of them are private goods, consumption $c$ and leisure $l \in[0,1]$. Individuals need to exert effort to obtain consumption, which is defined as $e=1-l$. There is also a public good, personal liberties $\ell \in\left[0, \ell_{M}\right]$. The maximum liberties accessible, $\ell_{M}$, is determined by law. The cap on liberties $\ell_{M}$ has two effects. First, it establishes the limit to what is accessible to individuals. Second, it may produce an externality because individuals may dislike to being in a society where some liberties are permitted, independently of whether or not they will personally use them. 
ELMa represent the effect of liberties on an individual as the combination of the personal use of them, $\ell$, and the maximum legally permitted, $\ell_{M}$, this being multiplied by the parameter $\alpha \in[0,1]$. This parameter indicates the weight assigned to the externality effect. ${ }^{8}$

Individuals are endowed with a "religiosity" index $x \in[0,1]$. ELMa parameterize the difference in the individual preferences over liberties by assuming that the utility function over consumption, liberties, and leisure, can be written as

$$
u\left(c,(\bar{x}-x)\left[\ell+\alpha \ell_{M}\right], 1-e\right),
$$

where $u(\cdot, \cdot, \cdot)$ is common to all individuals and $\bar{x}$ is the threshold level of religiosity separating those that value liberties positively with $x \leq \bar{x}$ (we call them secular) from those that value them negatively, with $x>\bar{x}$ (the religious). Notice that the higher the degree of religiosity, the lower the utility [all equal]. Under standard assumptions in consumer theory higher religiosity produces lower marginal utility of consumption and of leisure. ${ }^{9}$ If the effect on the marginal utility of consumption is larger [in absolute terms] than on leisure, the supply of effort is decreasing as religiosity increases. In view of the assumed utility function, it is immediate that the difference in labor supply induced by religiosity is amplified by the width of personal liberties $\ell_{M}$.

ELMa show that if the effect on the marginal utility of consumption is larger than on leisure ${ }^{10}$ then,

[1] religiosity has a negative effect on effort and the effect is larger the higher the cap of liberties afforded, that is, the interaction of religiosity and liberties has a negative effect on labor supply; and

[2] the effect of liberties on labor supply is positive for secular and negative for religious.

4.1. Empirical Evidence. Using data for European countries, ELMa obtain that [1] and [2] hold empirically. The analysis employs the above-described Liberties Index as well as data from the European Social Surveys on religiosity, labor supply and other controls. ${ }^{11}$ Based on the personal liberties index mentioned above, ELMa construct an individual-specific index that reflects the level of liberties at different stages of the individual's life cycle, as some decisions are specific to some particular stage, like decisions on education or birth control. To that effect, ELMa average the values of the liberties index corresponding to the years when that individual was between 18 and 40 years of age.

ELMa estimate the following equation:

(2) $e_{i, j, s}=\beta_{0}+\beta_{1} \operatorname{Rel}_{i, j, s}+\beta_{2} \operatorname{Re}_{i, j, s} \times \ell_{i, j, s}+\beta_{3} \ell_{i, j, s}+X_{i, j, s}^{\prime} \beta+\gamma Z_{j}+\delta Y_{s}+\mu Z_{j} \times Y_{s}+\epsilon_{i, j, s}$

\footnotetext{
${ }^{8}$ The analysis is robust to the externality arising instead from the actual practice of wider liberties by some individuals in society. It is also robust to considering different values for religious and secular individuals.

${ }^{9}$ ELMa assume the standard properties on $u(\cdot, \cdot, \cdot)$ : the utility increases in all arguments, satisfies concavity with respect to each argument, and has non-negative cross derivatives.

${ }^{10}$ If the opposite holds then the implications are reversed.

${ }^{11}$ Data from rounds 2002, 2004, 2006, 2008, 2010 and 2012 are employed for all countries available (at most 34, including Turkey and Israel).
} 


\begin{tabular}{|c|c|c|c|c|c|c|}
\hline & {$[1]$} & {$[2]$} & {$[3]$} & {$[4]$} & {$[5]$} & [6] \\
\hline REL $_{\text {INT }}$ & $\begin{array}{r}-0.551 \\
(0.185)\end{array}$ & $\begin{array}{r}3.355^{* * * *} \\
(0.007)\end{array}$ & $\begin{array}{r}3.794 * * * \\
(0.004)\end{array}$ & $\begin{array}{r}-0.904 \\
(0.398)\end{array}$ & $\begin{array}{r}6.820 * * \\
(0.013)\end{array}$ & $\begin{array}{r}7.089 * * \\
(0.014)\end{array}$ \\
\hline $\mathrm{LIB}_{40}$ & $\begin{array}{r}0.220 \\
(0.887)\end{array}$ & $\begin{array}{r}3.189 * * \\
(0.036)\end{array}$ & $\begin{array}{r}3.414 * * \\
(0.030)\end{array}$ & $\begin{array}{r}0.450 \\
(0.767)\end{array}$ & $\begin{array}{r}5.752 * * * \\
(0.004)\end{array}$ & $\begin{array}{r}5.788^{* * * *} \\
(0.005)\end{array}$ \\
\hline $\mathrm{REL}_{\mathrm{INT}} \times \mathrm{LIB}_{40}$ & & $\begin{array}{r}-8.669 * * * \\
(0.002)\end{array}$ & $\begin{array}{r}-9.226 * * * \\
(0.002)\end{array}$ & & $\begin{array}{r}-16.451 * * \\
(0.011)\end{array}$ & $\begin{array}{r}-16.929 * * \\
(0.013)\end{array}$ \\
\hline AGE & $\begin{array}{r}0.063 \\
(0.377)\end{array}$ & $\begin{array}{r}0.082 \\
(0.230)\end{array}$ & $\begin{array}{l}0.131^{*} \\
(0.050)\end{array}$ & $\begin{array}{r}0.051 \\
(0.487)\end{array}$ & $\begin{array}{r}0.089 \\
(0.196)\end{array}$ & $\begin{array}{r}0.131 * * \\
(0.046)\end{array}$ \\
\hline $\mathrm{AGE}^{2}$ & $\begin{array}{l}-0.001 \\
(0.299)\end{array}$ & $\begin{array}{l}-0.001 \\
(0.165)\end{array}$ & $\begin{array}{r}-0.002 * * \\
(0.027)\end{array}$ & $\begin{array}{l}-0.001 \\
(0.402)\end{array}$ & $\begin{array}{l}-0.001 \\
(0.129)\end{array}$ & $\begin{array}{r}-0.002 * * \\
(0.021)\end{array}$ \\
\hline GENDER & $\begin{array}{r}-7.666 * * * \\
(0.000)\end{array}$ & $\begin{array}{r}-7.676 * * * \\
(0.000)\end{array}$ & $\begin{array}{r}-7.677 * * * \\
(0.000)\end{array}$ & $\begin{array}{r}-7.586 * * * \\
(0.000)\end{array}$ & $\begin{array}{r}-7.633 * * * \\
(0.000)\end{array}$ & $\begin{array}{r}-7.620 * * * \\
(0.000)\end{array}$ \\
\hline CHILDREN & & & $\begin{array}{r}-0.555^{* *} \\
(0.030)\end{array}$ & & & $\begin{array}{r}-0.720 * * * \\
(0.002)\end{array}$ \\
\hline EDUYRS & & & $\begin{array}{r}0.067 \\
(0.230)\end{array}$ & & & $\begin{array}{l}0.102 * \\
(0.060)\end{array}$ \\
\hline HHSIZE & & & $\begin{array}{r}-0.063 \\
(0.568)\end{array}$ & & & $\begin{array}{r}0.033 \\
(0.716)\end{array}$ \\
\hline HEALTH & & & $\begin{array}{r}-0.019 \\
(0.852)\end{array}$ & & & $\begin{array}{r}-0.010 \\
(0.926)\end{array}$ \\
\hline EDU-PTNR & & & $\begin{array}{r}-0.060 \\
(0.258)\end{array}$ & & & $\begin{array}{r}-0.035 \\
(0.470)\end{array}$ \\
\hline $\mathrm{c}$ & $\begin{array}{r}43.009 * * * \\
(0.000)\end{array}$ & $\begin{array}{r}41.219 * * * \\
(0.000)\end{array}$ & $\begin{array}{r}43.688 * * * \\
(0.000)\end{array}$ & $\begin{array}{r}52.155^{* * * *} \\
(0.000)\end{array}$ & $\begin{array}{r}48.080 * * * \\
(0.000)\end{array}$ & $\begin{array}{r}46.827 * * * * \\
(0.000)\end{array}$ \\
\hline $\begin{array}{l}\mathrm{R}^{2} \\
\mathrm{Obs}\end{array}$ & $\begin{array}{r}0.148 \\
98200\end{array}$ & $\begin{array}{r}0.149 \\
98200\end{array}$ & $\begin{array}{r}0.150 \\
96448\end{array}$ & $\begin{array}{r}0.149 \\
91055\end{array}$ & $\begin{array}{r}0.150 \\
91055\end{array}$ & $\begin{array}{r}0.151 \\
89418\end{array}$ \\
\hline $\begin{array}{l}\text { K-P test } \\
\text { Cragg-Donald } \\
\text { Anderson-Rubin test }\end{array}$ & & & & $\begin{array}{r}499 \\
22815 \\
0.4052\end{array}$ & $\begin{array}{r}272 \\
15942 \\
0.028\end{array}$ & $\begin{array}{r}270 \\
10687 \\
0.031\end{array}$ \\
\hline
\end{tabular}

Table 1. BASELINE: EFFORT, RELIGIOUS INTENSITY AND LIBERTIES, OLS AND 2SLS Notes. Dependent variable is HOURSWORKED. All models contain country, survey and country-survey dummies. Columns 1-3 have been estimated by OLS while columns 4-6 by 2SLS. There are 34 countries. Robust standard errors clustered at the country level have been computed. p-values are in parentheses.

where $i$ and $j$ and $s$ denote individual, country and survey year, respectively, $e$ denotes individual labor supply, $R e l$ is a proxy of individual religiosity $(x), \ell$ is the individual-specific index of liberties ( LIB $\left._{40}\right), X$ contains individual controls, and $Z$ and $Y$ are country and survey dummies, respectively.

ELMa results imply that $\beta_{2}<0$ and $\beta_{3}>0$, that is, the marginal impact of an increase in the cap on liberties $\ell$ on effort is positive for low levels of religiosity but it becomes negative when religiosity is high. The turning point of this equation allows us to identify $\bar{x}$, the threshold separating religious and seculars, which is given by $\bar{x}=-\beta_{3} / \beta_{2}$. They use the estimated coefficients to identify the value of $\bar{x}$. A final implication of this theory is that the marginal effect of religiosity on effort is overall negative. ELMa estimate this equation by OLS and by 2SLS using an instrument for individual religiosity described in detail there. 
Table 1 contains the baseline results. The dependent variable is the total amount of hours worked per week (in main job), including any paid or unpaid overtime (HOURSWORKED). ${ }^{12}$ Column 2 regresses HOURSWORKED on religious intensity $\left(\mathrm{REL}_{\mathrm{INT}}\right)$, our individual-specific index of personal liberties $\left(\mathrm{LIB}_{40}\right)$, the interaction of these two variables, as well as some exogenous individual characteristics (gender and age) and country, survey and country-survey dummies. ${ }^{13}$ The coefficient of the interacted term is highly significant, as our theory predicts, and is negative, suggesting that the negative effect of religiosity on effort is amplified by the availability of liberties. The coefficient associated with LIB $_{40}$, that captures the effect of liberties on effort when $\mathrm{REL}_{\mathrm{INT}}$ is close to zero, is positive and significant at the $5 \%$ level which means that liberties are an incentive for the secular. On the other hand, the effect of $R \mathrm{LL}_{\mathrm{INT}}$ is positive and significant suggesting that for moderate values of $\mathrm{LIB}_{40}$ the overall effect of $\mathrm{REL}_{\mathrm{INT}}$ is ambiguous. Column 3 shows that the results continue to hold when other individual controls are introduced in the regression. ${ }^{14}$

As there are good reasons to believe that $\mathrm{REL}_{\mathrm{INT}}$ can be endogenous, we have reestimated columns $1-3$ by 2 SLS using an instrument for religiosity. To construct an instrument for REL $_{\mathrm{INT}}$, ELMa exploit the fact that religiosity is a cultural trait that transcends national borders in the European environment. That is, people belonging to a particular religious denomination are likely to have similar beliefs and attitudes towards topics regulated by their religions. They construct an instrument for $\mathrm{REL}_{\mathrm{INT}}, \mathrm{REL}_{\mathrm{INT}}^{\mathrm{IV}}$, as follows: for an individual $i$ from country $j$ with (current or past) religious denomination $r$, we consider the people of the same religious denomination, gender and age bracket living in the countries that share a border with country $j .{ }^{15}$ We consider neighbouring countries so that similarities between national customs are more pronounced. Next, we compute the average value of $\mathrm{REL}_{\mathrm{INT}}$ for those individuals. The resulting quantity is the value of REL IVT for individual $i$ in country $j$. As the instrument is the average of other people's religiosity, by construction it is uncorrelated with individual i's "innate" characteristics, such as ability. ${ }^{16}$

Columns 4-6 in Table 1 reestimate columns $1-3$ by 2 SLS, instrumenting religious intensity with the above-described instrument. The results are very similar and for the sake of brevity, we focus on column 6 , our baseline specification henceforth, which reestimates column 3 in the same table. This column shows that the interaction of religiosity and liberties has a negative and

\footnotetext{
${ }^{12}$ Notice, however, that HOURSWORKED is an imperfect measure of the willingness to work, as it reflects attitudes towards effort as well as the characteristics of the environment (i.e., rigidity of the labor market). To address this issue, ELMa also consider a variable that reports the number of hours that the respondent would like to work (DESIREDHOURS).

${ }^{13}$ Religious intensity is computed as the average of three variables: (i) the respondent's monthly frequency of praying, (ii) the self-reported degree of religiosity, and (iii) the respondent's monthly frequency of attendance of religious services.

${ }^{14}$ These additional controls are: whether the respondent lives with a partner (COHAB), years of completed education (EDUYRS), a subjective measure of own's health (HEALTH), whether there are children in the household (CHILDREN), the size of the household (HHSIZE) and a measure of partner's education (EDU-PTNR).

${ }^{15}$ We define three age brackets: from 18 to 35 , from 36 to 60 and from 60 onwards. Results are robust to changes in the definition of the brackets.

${ }^{16}$ We construct the instrument for the interaction term of religious intensity and liberties simply by replacing $\mathrm{REL}_{\mathrm{INT}}$ by $\mathrm{REL}_{\mathrm{INT}}^{\mathrm{IV}}$ in the product.
} 
significant effect on labor supply while the coefficient on religiosity is positive and significant. As mentioned before, the overall effect of religiosity is then, ambiguous, especially for moderate values of $\mathrm{LIB}_{40}$.

The magnitude of the effect of religiosity on effort is quite sizeable among individuals that have access to liberties. Focusing again on column 6 in Table 1, an increase in one standard deviation in the intensity of religious beliefs is associated with a decrease in the number of hours worked per week of $0.75,1.39$ or 1.8 hours for individuals with a value of $\operatorname{LIB}_{40}$ in the 75 th, 95 th and 99th percentile, respectively.

The second prediction of the model states that liberties provide differential incentives to religious and seculars. As noted above, the value of $\bar{x}$, the threshold separating religious from seculars, is $\bar{x}=-\beta_{3} / \beta_{2}$, where $\beta_{2}$ and $\beta_{3}$ are the coefficients associated to $\mathrm{REL}_{\mathrm{INT}} \times \mathrm{LIB}_{40}$ and $\mathrm{LIB}_{40}$ respectively. Using the values of these coefficients from column 6 of Table 1 , a value of $\bar{x}=.34$ is obtained. This value corresponds to the percentile 57 of the distribution of $\mathrm{REL}_{\mathrm{INT}}$, which means that an increase in $\mathrm{LIB}_{40}$ translates into an increase in the amount of hours worked for almost $60 \%$ of the population in Europe (the secular). For the remaining $40 \%$ (the religious), an expansion of the legal cap on liberties has a negative effect on their labor supply.

Finally, the magnitude of the effect of liberties on effort is large for both seculars and religious. We provide two examples, for individuals in the 20th and in the 80th percentile of the distribution of $\mathrm{REL}_{\mathrm{INT}}$. In the former case, an increase in one standard deviation in $\mathrm{LIB}_{40}$ increases by .72 hours per week the number of hours worked. In the latter, a similar increase reduces by .92 hours the weekly amount of hours worked.

\section{Religiosity, LIBERTIES, AND Voting}

From the assumption that religiosity shapes the valuation of individual liberties we have derived that the interaction between religiosity and liberties is a key variable in determining labor supply. Wider liberties enlarge the gap in labor supply -hence income- between religious and secular. Consequently, the distribution of religiosity over the population and the legal cap on liberties influences the extent of income inequality and hence the demand for redistribution. But at the same time, the outcome of the vote over liberties will change the incentives of the individuals and hence have an effect on who the median voter is. This is the problem studied by ELMb.

The link between the preferences of poor individuals for low taxation is documented in, among others, Guiso, Sapienza and Zingales (2006). Huber and Stanig (2007) argue that the right-wing positioning of poor religious individuals is driven by a "forced choice" provoked by the specific policy mix furnished by conservative parties. Chen and Lind (2016), Ceyhun et al (2013) and Huber and Stanig (2011) argue that the lower support for redistribution by the religious results from the preference for social assistance and redistribution within the own religious community. In Scheve and Stasavage (2006) -see also Gill and Lansgaarde (2004) and Clark and Lelkes (2004) - the psychic benefit from religion allows individuals to cope with bad states which reduces the need for social insurance and hence religious individuals prefer less redistribution and social assistance. In Bénabou and Tirole (2006) religion is a way of manipulating one's beliefs in order to motivate continued effort and therefore religious agents will work harder and demand 
less taxes. A similar argument is made by Huber and Stanig (2011) and Bénabou et al (2015a, 2015b). Roemer (1998) formalizes the voting over redistribution and religious provisions and shows that all parties may propose relatively moderate taxes as a result of the two-dimensional competition.

ELMb contribute to this literature by studying the vote on redistribution and personal liberties by individuals that differ in their productivity and in their esteem for liberties -their religiosity. Besides, the problem also has the novelty that the vote for the cap on personal liberties has a side incentive effect on labor supply and hence on inequality and the demand for redistribution.

How does this effect of religiosity and liberties on income inequality translate into political voting? Using a similar model as in the previous section, ELMb examine the outcome of sequential voting, first on the cap on liberties and next on the marginal tax rate -for the family of linear tax functions. While changes in the tax schedule can take place yearly together with the voting of the government's budget, changes in the legislation on liberties are far less frequent.

Voters are assumed to be aware that the outcome of the vote on liberties defines a set of incentives for work that will determine each individual's preference for redistribution, as well as who is the median voter in the second stage. In order to make the problem tractable, ELMb simplifies the environment to two productivity types, high and low, and two religiosity levels, high (religious) and low (secular). It is assumed that low productivity individuals are in a majority.

ELMb's argument can be summarized as follows. Suppose that the secular are in a majority. Then they will impose full liberties in the first stage of the voting because it is their best choice independently of the continuation. In the second stage, the tax chosen is the one preferred by the median voter, given that there are full liberties. Nothing unexpected arises in the case of a secular majority.

When the religious are in a majority there is more room for strategic behavior in voting. Observe that the religious with low productivity will always earn the lowest income and that the secular with high productivity will earn the highest. Let us now consider the religious poor. They face a dilemma with respect to their potential support for liberties, when taking into account that they will not be pivotal in the second stage. Because of their religiosity they will experience a utility loss if wider liberties are chosen. However, under full liberties work incentives for the secular will be largest and this results in a larger tax base and larger net transfers to the lowest incomes.

Which one dominates depends on the gap in religiosity between secular and religious relative to the gap in productivities between low and high productivity. The incentive effect of liberties on earned income by the secular depends on how wide the religious gap is. Therefore, under a religious majority, if differences in productivity are large relative to differences in religiosity, the low productivity secular will be pivotal in the second stage and will demand substantial redistribution. In this case, the religious of low productivity might vote for liberties in order to have redistribution in the second stage. However, if the gap in religiosity is large enough, the religious majority will vote for repression in the first stage, knowing that under repression all the low productivity individuals will vote for the same level of redistribution.

Summing up, ELMb result is that the outcome of the voting process critically depends on whether the majority is made of secular or of religious individuals, and also depends on the relative size 
of the religious and productivity gaps. When the secular are in a majority, the political outcome is full liberties and the tax preferred by the low productivity secular. When the religious are in a majority we have that: [i] when the religiosity gap is sufficiently wide the religious majority represses liberties and also votes for low redistribution; [ii] when the productivity gap is dominant but small the religious vote for liberties and high taxation; and [iii] when the productivity gap is large enough the religious majority chooses full liberties and moderate redistribution.

\section{CONCLUding REMARKS}

In the last fifty years, Western countries have witnessed an unprecedented change in the legal regulations pertaining to individual liberties, such as women's rights for education or employment, abortion, divorce, LGBT rights, euthanasia, etc. Those regulations have evolved from almost mimicking the religion codes of conduct to becoming far more tolerant. To the extent that such legal limits were an effective constraint for the most secular part of the population, the sequential lifting of these constraints must have had important effects on individual choices. These effects have been both direct -since the lifting of the legal constrains permits actions that were forbidden before- as well as indirect, because a more tolerant legislation can be perceived as a positive or a negative externality, depending on individuals' preferences. That is, irrespective of the individual use of all or some of those liberties, individuals may like or dislike to live in a more permissive society.

There are many interesting open questions that deserve attention. Why this change in legislation has taken place? Is it that religiosity among the population has changed and this has mapped into a more liberal legislation? If so, which factors have driven such a change in religiosity? Is it the case that the change in the legal caps -and the induced change in behavior of some- has had an effect on the social interpretation of the norms and codes of conduct? Have the changes in the legislation further induced secularization of society? There is little doubt that this is a phenomenon in which causality is likely to operate both ways.

The work in ELMa,b is but a first step in the study of the causes and consequences of the "human rights revolution". Their results can be interpreted as providing a possible explanation for our first question: why has legislation changed so much? Their point is that, in order to relax the regulation on liberties, we don't need to appeal to the vote of a potential majority of the secular, a change that in most cases -notably in the US- apparently has not taken place. ELMb show that an economic shock that widens the gap in productivities -thus, increasing income inequality-is enough to induce the low income religious individuals to support a more relaxed legislation on personal liberties, even when the religious are in a majority. This of course should be supplemented with the study of the subsequent effect of the change in behavior of part of society on personal levels of religiosity.

ELMb also starts exploring in the direction proposed by Becker (1996), suggesting that religiosity might be manipulated by the elite. They find that the elite prefers that the low productivity individuals are split into secular and religious, rather than all being religious (or secular). This is so because either type of homogeneity, by making all the poor alike, would lead to higher demands for redistribution. But if the low productivity are split, the secular individuals will impose lower demands for redistribution because their income is higher than the religious poor. 
Our last remark concerns the significant role of externalities in shaping individual preferences and behaviour, accordingly with our empirical results. The externality effect of liberties can be viewed as a cultural factor specific to each religion. In our model, religions that are more individualistic (such as Protestantism, that focuses on the personal relationship with god, independently of what the others might be doing) could induce a less negative effect of wider liberties on labor effort. Hence, differences across religions in the weight assigned to the externality of liberties could explain differences in individual and aggregate labor effort across countries. This would provide an explanation complementary to Weber's (1904) as to why Protestantism became more conducive to economic growth than Catholicism. We leave for future research the precise identification and measurement of this externality factor across different cultures and religious affiliations.

\section{REFERENCES}

[1] Azzi, C. and R. Ehrenberg (1975), "Household Allocation of Time and Church Attendance", Journal of Political Economy, 83, 27-56.

[2] Barro, Robert and Rachel McCleary (2003). "Religion and Economic Growth across Countries", American Sociological Review. 68, 760-81.

[3] Becker, Gary (1996) "Norms and the Formation of Preferences" in G. Becker Accounting for Tastes, University of Chicago Press.

[4] Becker, Sascha O. and Ludger Woessmann (2009) "Was Weber Wrong? A Human Capital Theory of Protestant Economic History”. Quarterly Journal of Economics, 124, 531?596,

[5] Bénabou Roland, Davide Ticchi and Andrea Vindigni (2015a), "Forbidden Fruits: The Political Economy of Science, Religion, and Growth", NBER Working Paper 21105.

[6] Bénabou, Roland, Davide Ticchi, and Andrea Vindigni (2015b). "Religion and Innovation.” American Economic Review, $P \& P, 105(5), 346-51$.

[7] Bénabou, Roland and Jean Tirole (2006) "Belief in a Just World and Redistributive Politics" Quarterly Journal of Economics, 121, 699-746.

[8] Bénabou, Roland and Jean Tirole (2011) "Identity, Morals and Taboos: Beliefs as Assets," Quarterly Journal of Economics, 126, 805-855.

[9] Berman, Eli (2000). "Sect, Subsidy and Sacrifice: An Economist's View of Ultra-Orthodox Jews. Quarterly Journal of Economics. 115, 905-953.

[10] Botticini, Maristella and Zvi Eckstein (2012) The Chosen Few: How Education Shaped Jewish History, 70-1492. Princeton University Press.

[11] Bisin, Alberto and Thierry Verdier (2000) "Beyond the Melting Pot: Cultural Transmission, Marriage, and the Evolution of Ethnic and Religious Traits," Quarterly Journal of Economics 115, 955-988.

[12] Bisin, Alberto and Thierry Verdier (2001) "The Economics of Cultural Transmission and the Dynamics of Preferences," Journal of Economic Theory, 97, 298-319.

[13] Campante, Filipe, and David Yanagizawa-Drott (2015), "Does Religion Affect Economic Growth and Happiness? Evidence from Ramadan", Quarterly Journal of Economics 130, 615-658.

[14] Cantoni, Davide (2015) "The Economic Effects of Protestant Reformation: testing the Weber Hypothesis in the German Lands" Journal of the European Economic Association 13, 561 ?598.

[15] Carvalho, Jean-Paul and Mark Koyama (2016), "Development and Religious polarisation: The Emergence of Reform and Ultra-Orthodox Judaism.”, Journal of Comparative Economics 44, 562-584.

[16] Ceyhun, Elgin, Turkmen Goksel, Mehmet Gurdal, and Cuneyt Orman (2013). "Religion, income inequality, and the size of the government," Economic Modelling, 30, 225-234.

[17] Chen, Daniel L. and Jo Thori Lind, (2016) “The Political Economy of Beliefs: Why Fiscal and Social Conservatives/Liberals (Sometimes) Come Hand-in-Hand?, TSE Working Paper, n. 16-722.

[18] Clark, A., and O. Lelkes, (2005). "Deliver Us From Evil: Religion as Insurance". Mimeo, DELTA, Paris. 
[19] Darnell, Alfred and Darren E. Sherkat. (1997). "The Impact of Protestant Fundamentalism on Educational Attainment." American Sociological Review 62, 306-316.

[20] De La O, Ana, and Jonathan Rodden (2008). "Does Religion Distract the Poor? Income and Issue Voting Around the World." Comparative Political Studies 41, 437-76.

[21] Delacroix, J. and F. Nielsen (2001). "The beloved myth: Protestantism and the rise of industrial capitalism in nineteenth-century Europe”. Social Forces, 80, 509-553.

[22] Durlauf, S., A. Kourtellos, and C. M. Tan (2012) "Is God in the Details? A Reexamination of the Role of Religion in Economic Growth," Journal of Applied Econometrics, 27, 1059-1075.

[23] Esteban Joan, Gilat Levy and Laura Mayoral (2017a), "Personal Liberties, Religiosity, and Effort ", mimeo.

[24] Esteban Joan, Gilat Levy and Laura Mayoral (2017b) "Liberté, Égalité, et ... Religiosité ”, mimeo.

[25] Gill, Anthony and Erik Lundsgaarde (2004) "State Welfare Spending and Religiosity. A Cross-National Analysis", Rationality and Society 16, 399-436.

[26] Grier, Robin (1997), “The Effect of Religion on Economic Development: A Cross National Study of 63 Former Colonies", Kyklos 50, 47-62

[27] Guiso, Luigi, Paola Sapienza, and Luigi Zingales (2003). "People's opium? Religion and economic attitudes." Journal of Monetary Economics, 50, 225-282.

[28] Guiso, Luigi, Paola Sapienza, and Luigi Zingales (2006). “Does Culture Affect Economic Outcomes?” Journal of Economic Perspectives 20, 23-48.

[29] Hitchcock, William, Akira Iriye, and Petra Goedde (2012). The Human Rights Revolution: An International History, New York: Oxford University Press.

[30] Huber, John and Piero Stanig (2006) "Individual income and voting for redistribution across democracies", unpublished wp.

[31] Huber, John and Piero Stanig (2011) "Church-state separation and redistribution" Journal of Public Economics, 95, 828-836.

[32] Iannaccone, Laurence R. (1992). "Sacrifice and stigma: reducing free-riding in cults, communes and other collectives," Journal of Political Economy. 100, 271-291.

[33] Iannaccone, Laurence R. (1998) "Introduction to the Economics of Religion", Journal of Economic Literature 36,1465 ? 1496.

[34] Inglehart, R. and P. Norris (2003), Rising Tide: Gender Equality and Cultural Change Around the World, Cambridge University Press.

[35] Lehrer, E.L. (1995). “The Effects of Religion on the Labor Supply of Married Women”. Social Science Research, 24, 281-301.

[36] Levy, Gilat and Ronny Razin (2012). "Religious Beliefs, Religious Participation and Cooperation.”, American Economic Journals: Micoreconomics, 4, 121-151.

[37] Lipford, Jody W. and Robert Tollison (2003) "Religious participation and income" Journal of Economic Behavior \& Organization, 51, 249-260.

[38] Marx, Karl $(1843,1976)$ Introduction to A Contribution to the Critique of Hegel's Philosophy of Right. Collected Works, v. 3. New York.

[39] McCleary, Rachel M. and Robert J. Barro (2006), "Religion and Economy" Journal of Economic Perspectives 20, 49-72.

[40] Nunn, Nathan (2010) "Religious Conversion in Colonial Africa." American Economic Review, 100, 147-152.

[41] Nunn, Nathan (2014) "Gender and Missionary Influence in Colonial Africa." In: Akyeampong E., Bates R., Nunn N, Robinson J.A. Africa's Development in Historical Perspective. New York: Cambridge University Press, pp. 489-512.

[42] Roemer, John E. (1998), "Why the poor do not expropriate the rich: an old argument in new garb", Journal of Public Economics 70, 399-424.

[43] Scheve, Keneth and David Stasavage (2006) "The Political Economy of Religion and Social Insurance in the United States, 1910-1939” Studies in American Political Development, 20 , 132-159

[44] Sherkat, D.E. and Darnell, A. (1999). "The effects of parents' fundamentalism on children's educational attainment." Journal for the Scientific Study of Religion, 38, 23-35.

[45] Solt, Frederick (2009), "Standardizing the World Income Inequality Database”. Social Science Quarterly, 90, $231 ? 242$. 
[46] Solt, Frederick, Philip Habel, and J. Tobin Grant (2011) "Economic Inequality, Relative Power, and Religiosity" it Social Science Quarterly 92, 447-465.

[47] Stegmueller, Daniel (2013) "Religion and Redistributive Voting in Western Europe". Journal of Politics 75 , 1064-1076.

[48] Weber, Max (1904). The Protestant Ethic and the Spirit of Capitalism. New York: Scribners. 